\title{
Tubular shell infestations in some Mississippian spirilophous brachiopods
}

Andrzej Baliński and Sun Yuanlin

Acta Palaeontologica Polonica 55 (4), 2010: 689-694 doi: http://dx.doi.org/10.4202/app.2010.0032

Evidence of brachiopod shell infestation by tube dwelling parasitic-commensal organisms is very rare in the fossil record. The oldest record of this kind of biotic interaction is known as Eodiorygma acrotretophilia from the Early Cambrian phosphatic acrotretoid Linnarsonia. The youngest evidence of parasitic infestation was documented in the Early Cretceous rhynchonellide Peregrinella multicarinata. Two other records of vermiform tubes inside brachiopod shells come from the Devonian. These are Diorygma atrypophilia, infesting Givetian atrypide shells, and Burrinjuckia spiriferidophilia, found in some Emsian spiriferides. Here we describe the fifth record of this kind of infestation for which a name Haplorygma dorsalis ichnogen. et ichnosp. nov. is proposed. The tubular infestation structure was revealed in two silicified dorsal valves of spirolophous brachiopods found in the Mississippian Muhua Formation of the Southern China. The affinity of the tube-dwelling organism is rather enigmatic, but its annelid relationship and kleptoparasitic nature seems highly probable. In addition, the phoronid affinity of Diorygma is here questioned.

Key words: Brachiopoda, Spiriferida, Spiriferinida, biotic interaction, endosymbionts, Mississippian, Muhua Formation, Southern China.

Andrzej Baliński [balinski@twarda.pan.pl], Instytut Paleobiologii PAN, ul. Twarda 51/55, PL-00-818 Warszawa, Poland; Yuanlin Sun [ylsun@pku.edu.cn], Department of Geology, Peking University, Beijing 100871, China.

This is an open-access article distributed under the terms of the Creative Commons Attribution License (for details please see creativecommons.org), which permits unrestricted use, distribution, and reproduction in any medium, provided the original author and source are credited. 
FoF Full text $(354.9 \mathrm{kB})$ 